
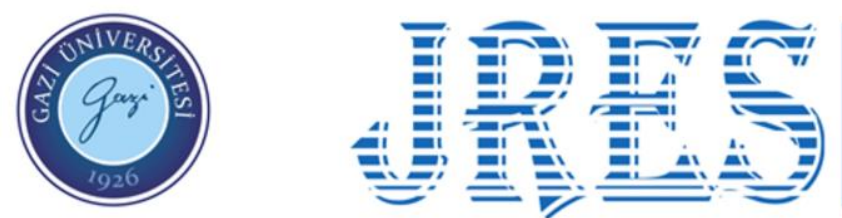

\title{
Farklı Öğretim Yaklaşımlarının Öğrencilerin Türk Grafik Sanatı Tarihi Konusundaki Başarılarına Etkisi*
}

\author{
The Effects of Different Teaching Approaches on Their Success in the Subject \\ of Turkish Graphic Art History
}

\section{Cihan Canbolat, Mehmet Ali Gökdemir}

\section{ÖZ}

Bu çalışmanın amacı “Türk Grafik Sanatı Tarihi” konusunun öğretiminde işbirlikli öğrenme ile sunuş yoluyla öğretim yaklaşımlarının öğrenci başarısı üzerindeki etkisini belirlemektir. Çalışma 2021-2022 öğretim yılı güz döneminde Kastamonu Üniversitesi, Güzel Sanatlar ve Tasarım Fakültesi Grafik Tasarım Bölümü'nde öğrenim gören 39 öğrenci ile yürütülmüştür. 1. sınıf 1. şubede öğrenim gören 20 öğrenciye işbirlikli öğrenme yaklaşımının birleştirme tekniği uygulanmış ve bu grup deney grubunu oluşturmuştur. 1. sınıf 2. şubede ise sunuş yoluyla öğretim yaklaşımının anlatım/soru-cevap teknikleri ile dersler işlenmiş ve bu grup kontrol grubunu oluşturmuştur. Çalışmanın başlangıcında, her iki gruptaki öğrencilerin hazırbulunuşluk düzeylerinin tespiti için araştırmacı tarafından hazırlanan ön test uygulanmıştır. Çalışmanın sonunda ise öğrencilerin "Türk Grafik Sanatı Tarihi” konusundaki başarılarının tespiti için son test uygulanmıştır. Verilerin analizinde SPSS paket programı kullanılmış, anlamlılık düzeyi .05 olarak alınmıştır. Yapılan istatistiksel analizler sonucunda sunuş yoluyla öğretim modelinin öğrencilerin ders başarılarına işbirlikli öğretim modelinden daha yüksek katkı sağladığı tespit edilmiştir.

\begin{abstract}
The aim of this study is to determine the effect of cooperative learning and teaching through presentation approaches on student success in teaching the subject of "History of Turkish Graphic Art". The study was carried out with 39 students studying at Kastamonu University, Faculty of Fine Arts and Design, Graphic Design Department in the fall semester of the 2021-2022 academic year. The combining technique of the cooperative learning approach was applied to 20 students studying in the 1st year 1st branch and this group formed the experimental group. In the 1st grade 2nd group, lessons were taught with the narration/question-answer techniques of the presentation approach and this group formed the control group. At the beginning of the study, a pre-test prepared by the researcher was applied to determine the readiness levels of the students in both groups. At the end of the study, a post-test was applied to determine the success of the students in the "History of Turkish Graphic Art". SPSS package program was used in the analysis of the data, and the level of significance was taken as 05 . As a result of the statistical analyses, it was determined that the presentation model made a higher contribution to the course success of the students than the cooperative teaching model did.
\end{abstract}

\section{Yazar Bilgileri \\ Cihan Canbolat iD \\ Arş. Gör. Dr., Kastamonu \\ Üniversitesi Güzel Sanatlar ve \\ Tasarım Fakültesi, Kastamonu, \\ Türkiye \\ cihancanbolat@kastamonu.edu.tr \\ Mehmet Ali Gökdemir (iD) \\ Öğr. Gör. Dr., Dicle Üniversitesi \\ Görsel Sanatlar Bölümü, \\ Diyarbakır, Türkiye \\ mali.gokdemir@dicle.edu.tr}

$\begin{array}{r}\text { Makale Bilgileri } \\ \text { Anahtar Kelimeler } \\ \text { Grafik sanatı } \\ \text { Sanat eğitimi } \\ \text { İşbirlikli öğrenme } \\ \text { Sunuş yoluyla öğrenme } \\ \text { Grafik tasarım } \\ \text { Keywords } \\ \text { Graphic art } \\ \text { Art education } \\ \text { Cooperative learning } \\ \text { Graphic design } \\ \text { Learning through presentation } \\ \text { Makale Geçmişi } \\ \text { Geliş: } 11 / 11 / 2021 \\ \text { Düzeltme: } 10 / 12 / 2021 \\ \text { Kabul: 10/12/2021 } \\ \hline \text { ilerin Türk grafik sanatı tarihi } \\ \hline \text { Yurulu'nun } \\ \hline\end{array}$

Atıf için: Canbolat, C. ve Gökdemir, M. A. (2021). Farklı öğretim yaklassımlarının öğrencilerin Türk grafik sanatı tarihi konusundaki başarılarına etkisi. JRES, 8(2), 336-344. https://doi.org/10.51725/etad.1021174

Etik Bildirim: Bu çalışma Kastamonu Üniversitesi Sosyal ve Beşeri Bilimler Araştırma ve Yayın Etiği Kurulu'nun 12.10.2021 tarih ve 18 sayılı onayı doğrultusunda gerçekleştirilmiştir.

* Bu çalışma, Gazi Üniversitesi Eğitim Bilimleri Enstitüsü tarafından 28-30 Haziran 2021 tarihleri arasında düzenlenen Genç Araştırmacılar Kongresi'nde sözlü bildiri olarak sunulmuştur. 


\section{Giriş}

Öğretimin temel amaçlarından biri başarıyı artırmaktır. Bu sebeple öğrenme-öğretme süreci verimli ders işlemeye odaklanmıştır. Başka bir deyişle bireyde kalıcı izli davranış değişikliğinin oluşması öğrenme-öğretme sürecinin etkili bir biçimde düzenlenmesine bağlıdır.

Öğrenme-öğretme sürecinde öğrencilerin "nasıl" öğreneceği sorusuna cevap aranır. Bu durumda eğitimi de öğrenci merkezli eğitime yönelmenin önemini ortaya koymaktadır. Öğrenci merkezli eğitimde asıl amaç, öğrenci katılımını sağlayarak eğitimde aktiflik ilkesini hayata geçirmek ve bilginin öğrenci tarafından yapılandırılmasını sağlamaktır (Özpolat, 2013, s. 8).

Öğrenci merkezli olarak planlanan öğretim süreci; öğretimin planlanması, uygulanması ve değerlendirilmesi aşamalarından oluşur. Öğretim sürecinin başarılı olabilmesi, büyük ölçüde nitelikli bir şekilde planlanmasına bağlıdır. Öğretimin planlanması kazandırılacak hedef davranışların belirlenmesi, içeriği organize etme, öğrenci niteliğine ve içeriğe uygun öğretim modeli seçme ile ölçme ve değerlendirme araçları hazırlama aşamalarından oluşur (Senemoğlu, 2011, s. 398).

Hedef davranışların kazandırılmasında uygun öğretim modelleri seçilmelidir. Öğretim modeline yönelik tanımlardan bazıları şu şekildedir: Karaağaçlı'ya (2011) göre “Öğretim modeli, öğretme ve öğrenmede farklı kuramların bir arada uygulanabildiği, aşamalı bir yapı içinde öğrenmelerin gerçekleştiği ve kazanımların somut olarak gözlenebildiği öğrenme-öğretme yardımcılarıdır" (s. 68). Öğretme modeli "Eğitim programını şekillendirmede, öğretim materyallerini düzenlemede, sinıfta ve diğer durumlarda öğretimi yönlendirmede kullanılabilen model ya da planlardır" (Joyce ve Weil'den aktaran Senemoğlu, 2011, s. 430). Farklı öğretim modellerinin kullanılması, farklı yollarla öğrenen öğrencilerin öğrenmesini kolaylaştırır. Çünkü her bireyin öğrenme şekli birbirinden farklıdır. Bu nedenle öğretim sürecinde kullanılan yöntem ve teknik öğrenci başarısında önemli rol oynar.

Öğretim modellerinden bazıları bireysel öğretim modelleri, bazıları ise grupla öğretim modelleridir. Görsel sanatlar eğitimi veren kurumlarda dersler genellikle bireysel çalışma ağırlıklı olarak işlenir. Oysa günümüzde her iki modelin zorunluluk haline geldiği söylenebilir. Bireysel çalışmada kişinin bireysel gelişimi hedeflenirken, grupla çalışma bireyin sosyal olarak gelişimini ve toplumun bir parçası haline gelmesini sağlar (Yılmaz, 2007, s. 747). Sanat eğitiminin bireysel yaratıcılık süreci gerektirdiği düs,üncesiyle ögretim yöntemleri konusunda ç,ok fazla araștırma yapılmamıștır. Oysa "düşünce tarzları ve sanat disiplinlerinin yöntemleri, yaratıcı çözümler gerektiren diğer disiplinlerdeki koșulları aydınlatmak için kullanılabilir" (Özsoy, 2003, s. 55).

Bu bağlamda sanat derslerinde yöntem sorunu, üzerinde durulması gereken bir konu olarak ele alınmalıdır. Tüm bu nedenlerle bu çalışmanın amacı, "Türk Grafik Sanatı Tarihi" konusunun öğretiminde kullanılan farklı öğretim yaklaşımlarının öğrencilerin başarıları üzerindeki etkisini belirlemektir.

\section{İşbirlikli Öğrenme Yaklaşımı}

İşbirlikli öğrenme modeli, öğrencilerin küçük gruplar halinde bir konunun öğretimini gerçekleştirmek ya da problemi çözmek amacıyla birlikte çalışmalarıyla gerçekleştirdikleri öğretimdir (Karaağaçlı, 2011, s. 211). Bu yöntem öğrencilerin işbirliği becerilerinin ön plana çıtığı, sosyal etkileşim ile öğrencilerin ihtiyaçlarına cevap verebilen, zihinsel yeteneklerini kullanmasını sağlayan, kendi öğrenmeleri ile ilgili kararlar almasına olanak veren bir öğretim yöntemidir (Özer, 2005, s. 112). 
İşbirlikli öğretim yaklaşımının genel özellikleri şunlardır:

Öğrenciler 4-6 kişilik gruplara ayrılır. Grupta her öğrenci konunun bir bölümünden sorumludur. Bireysel olarak herkesin çabası ortak çalışmalar içindir. Öğrenciler konuya/üniteye aktif ve paylaşımcı olarak katılırlar. İşbirlikli öğretim yaklaşımından öğretmen gözlem yapar, öğrencinin ihtiyaç duyduğu yerde ona rehberlik eder. Her öğrencinin üst düzeyde öğrenmesi öngörülür. İşbirlikli öğretim yaklaşımı öğrencilerin ortak ilgiler etrafında bir araya gelmesini sağlar. Grupta konunun eksik kalan yerlerin öğrenilmesinde ve öğretirken öğrenmeyi pekiştirirken öğrencilerin öğrenmesine katk1 sağlar. Bireysel çalışmaların yanında grup çalışmaları olarak da sürdürülebilir. Bilişsel öğrenmelerde etkili olarak uygulanır (Karaağaçli, 2011, s. 212-215).

En yaygın kullanılan işbirliğine dayalı öğrenme teknikleri şunlardır: 1- Öğrenci takımları ve Başarı Bölümleri (ÖTBB) 2- Takım- Oyun- Turnuva (TOT) 3- İşbirliğine Dayalı Birleştirilmiş Okuma ve Kompozisyon (IBOK) 4- Takım Destekli Bireyselleştirme (TDB) 5- Karşılıklı Sorgulama (KS) 6Birleştirme 7- Birleştirme II (Senemoğlu, 2011, s. 501).

İşbirliğine dayalı her bir öğrenme tekniğini uygularken tekniğe göre bazı farklılıklar olabilir. $\mathrm{Bu}$ araştırmada kullanılan Birleştirme tekniği Eliot Aronson tarafından geliştirilmiştir. Birleştirme tekniği uygulamasında gruplar 5-6 kişilik gruplara ayrılır. Konu ya da ünite gruptaki öğrenci sayısı kadar alt bölüme ayrılır. Her öğrenci kendi konusunu öğrenmek ve arkadaşına öğretmekle sorumludur. Konusunu araştıran öğrenciler bir sure sonra uzmanlık gruplarına ayrılırlar. Uzmanlık gruplarını aynı konuyu çalışan öğrenciler oluşturur. Öğrenciler konuyu derinlemesine tartıştıktan sonra asıl gruplarına dönerler ve tüm konu bu grupta öğrenilir (Özdilek, Erkol, Doğan, Doymuş ve Karaçöp, 2015, s. 213).

\section{Sunuş Yoluyla Öğretim Yaklaşımı}

Ausubel tarafından geliştiren ve bilişsel kurama dayalı olan sunuş yoluyla öğretim yaklaşımına göre öğrenme anlamlı ve akılda kalıcı olmalıdır. Öğretmen merkezli bir yaklaşım olan sunuş yoluyla öğretim ile öğrenciler konu ile ilgili bilgileri, kavramları ve ilkeleri sunulma yoluyla öğrenebilirler (Akınoğlu, 2018, s. 69). Açıklamanın gerektiği her durumda başarıyla uygulamabilecek bu yaklaşım bugün okullarda oldukça yaygın bir biçimde kullanılmaktadır (Bilen, 1996, s. 39).

Sunuş yoluyla öğrenme modelinin diğer ismi alış yoluyla öğrenmedir. Bu yaklaşım, bilginin aktarılması, ilke ve kavramların açıklanmasında kullanılır. Öğretmen ve öğrenci yoğun etkileşim içindedir. Öğretmen konuyu organize eder ve uygun öğretim materyallerini seçerek genelden özele (tümden gelim) doğru anlatır. Görsel ve işitsel uyarıcılarla konuyu destekler. Bol örnek verir. Öğrencinin öğrenmeyi anlamlandırıp anlamlandırmadığını soru-cevap yoluyla belirler. Öğrenme bilme, kavrama düzeyindedir (Sönmez, 2009, s. 209-210). Sunuş yoluyla öğretimde en çok kullanılan tekniklerden biri de anlatım ve soru cevap yöntemidir.

Anlatım yöntemi sözlü anlatım gerektiren bütün öğretim faaliyetlerinde kullanılan geleneksel bir yöntemdir. Her şeyden once ekonomiktir, esnektir, her türlü dinleyici grubuna kolaylıkla istenilen zaman ve mekanda uygulanabilir. Bu yöntemin avantajları olduğu kadar dezavantajları da bulunmaktadır. Büyük ölçüde kitabi bilgilere dayandığından, öğrencileri araştırma yapmak ya da bilgiyi kendisi keşfetmek yerine, kalıp bilgileri ezberlemeye sevk eder. Öğrencilerle sağlıklı iletişim kurulamaması durumunda konunun anlaşılıp anlaşılmadı̆̆ını ortaya koyacak geri bildirimler alınamaz, dersin kontrolü sağlanamaz (Ergün ve Özdaş, 1997, s. 31-35).

Sunuş yoluyla öğretimde kullanılan diğer teknik soru-cevap tekniğidir. Öğretimin temel araçlarından biri de soru sormaktır. Soru sormak kişinin problemi anlamaya çalıştığını ve çc̈züm için bir yol aradığını gösterir. Bu teknik ögrencinin başkalarını dinlemesini sağlar ve kendi fikirlerini 
üreterek kendini ifade etme gücünü geliș,irir. Öğrenciler derse aktif katılım sağlar. Soru cevap tekniği mükemmel bir öğretim metodu olmakla beraber konuyu bilen ve hakim olan öğrenciler için sıkıcı olabilir. Soruyu bilemeyen ve konuya hakim olamayan öğrencilerin kendilerine güveni azabilir. Sorucevap yönteminin en büyuik dezavantajlarından biri de, konunun çok fazla dağtılması, dersin "kaynatılması" ve dolayısıyla programın yetiștirilememesidir (Ergün ve Özdaş, 1997, s. 36-41).

\section{Amaç}

Bu çalışmanın amacı, "Türk Grafik Sanatı Tarihi” konusunun öğretiminde kullanılan farklı öğretim modellerinin öğrencilerin başarıları üzerindeki etkisini belirlemektir. Bu amaca yönelik daha ayrıntılı sonuçlara ulaşabilmek için aşağıdaki alt amaçlardan yararlanılmıştır:

1- İşbirlikli Öğrenme (deney grubu) ile Sunuş Yoluyla Öğretim (kontrol grubu) yaklaşımlarıyla işlenen "Türk Grafik Sanatı Tarihi” konusunda öğrencilerin ön test ve son test puanları arasında anlamlı bir fark var mıdır?

2- İşbirlikli Öğrenme (deney grubu) ile Sunuş Yoluyla Öğretim (kontrol grubu) yaklaşımlarıyla işlenen "Türk Grafik Sanatı Tarihi” konusunda öğrencilerin son test başarı puanları arasında anlamlı bir fark var mıdır?

\section{Önem}

İlgili alan yazın incelendiğinde Grafik Tasarım derslerinin işlenişinde farklı öğretim modellerinin etkisini araştıran çalışmaların oldukça sınırlı olduğu görülmüştür. Bu çalışma ile ilgili alana katkı yapılacağı düşünülmektedir.

Ayrıca bir konunun öğrenciler tarafından yeterince öğrenilmesinde öğretim yönteminin etkisi büyüktür. Bu açıdan hangi öğretim yönteminin öğrenci başarısı üzerinde daha etkili olduğunun tespitine yönelik çalışmaların yapılması önem arz etmektedir.

Bu bilgiler ışığında bu çalışmanın “Türk Grafik Sanatı Tarihi” konusunun öğrenciler tarafından hangi öğretim yaklaşımı ile daha iyi öğrenileceğinin belirlenmesinde yol gösterici olacağı düşünülmektedir.

\section{Sinirlılıklar}

Bu çalışma 2021-2022 öğretim yllında Kastamonu Üniversitesi Güzel Sanatlar ve Tasarım Fakültesi Grafik Tasarım Bölümü 1. sınıf öğrencileri ile araştırmacı tarafından geliştirilen veri toplama araçları ile sınırlıdır.

\section{Yöntem}

$\mathrm{Bu}$ araştırma; gerçek deneme modellerinden ön test-son test kontrol gruplu model kullanılarak gerçekleştirilmiştir. Gerçek deneme modelleri, deneysel çalışmalarda en çok tavsiye edilen modellerdir. Gerçek deneysel desenlerin en önemli özelliği, deney ve control gruplarına rastgele (Random, Seçkisiz) katılımcı sağlamaktır. Böylelikle, iç geçerliği ihlal edecek bir takım sorunlar kontrol altına alınmış olur (Akbay, 2021, s. 165).

Bilimsel değeri en yüksek denemeler, gerçek deneme modelleriyle yapılanlardır. Gerçek deneme modellerinin ortak özellikleri, birden çok grup kullanılması ve grupların yansız atama (örnekleme) ile oluşturulmasıdır. Ön test-son test kontrol gruplu modelde, yansız atama ile oluşturulmuş iki grup bulunur. Bunlardan biri deney, diğeri kontrol grubu olarak kullanılır. Her iki grupta da deney öncesi ve deney sonrası ölçmeler yapılır (Karasar, 2016, s. 120-121). 
Araştırmanın bağımsız değişkenini "Türk Grafik Sanatı Tarihi” konusunun Sunuş Yoluyla Öğretim Modeli ve İşbirlikli Öğretim modeli ile işlenmesi, bağımlı değişkenini ise; öğrencilerin başarı puanları oluşturmuştur.

\section{Evren ve Örneklem}

Araştırmanın çalışma grubunu, 2021-2022 öğretim yılı güz döneminde Kastamonu Üniversitesi, Güzel Sanatlar ve Tasarım Fakültesi Grafik Tasarım Bölümü'nde öğrenim gören öğrenciler oluşturmuştur. Örneklemini ise; yine 2021-2022 öğretim yılı güz döneminde öğrenim görmekte olan ve Grafik Tasarım Bölümü'nde öğrenim gören 1. sınıf öğrencileri oluşturmuştur. 2021-2022 öğretim yılı güz dönemi Grafik Tasarımı Bölümü 1. sınıf öğrencilerinden, rastgele (Random) atama yöntemi kullanılarak, bir grup Sunuş Yoluyla Öğretim Modelinin uygulanacağı kontrol grubu; bir grup da İşbirlikli Öğrenme Modelinin uygulanacağı deney grubu olarak belirlenmiştir. Bu durumda, 1. sınıf 1 . şubede yer alan 20 öğrenci deney grubunu; 1 . sinıf 2. şubede yer alan 19 öğrenci ise kontrol grubunu oluşturmuştur.

Kontrol ve deney gruplarından elde edilen verilerin üzerinde yapilacak olan istatistiksel analizlere karar vermeden önce, her iki grubun da normal dağılım gösterip göstermediği ve varyansların homojen olup olmadığı test edilmiştir.

\section{Veri Toplama Araçları}

"Türk Grafik Sanatı Tarihi" konusuna yönelik öğrencilerin ön test ve son test başarı puanlarını elde edebilmek için araştırmacı tarafından uzman görüşü alınarak geliştirilen ve 20 sorudan oluşan iki ayrı çoktan seçmeli test kullanılmıştır.

Testlerden ilki öğrencilerin ön test puanlarını, ikincisi ise son test puanlarını elde edebilmek için kullanılmıştır. Her iki test, grafik tasarım alanında üç uzman tarafından kontrol edilerek düzeltilmiştir. Uzmanlar tarafından verilen düzeltmeler doğrultusunda araştırmacı testlere son halini verilmiştir.

\section{Verilerin Toplanması}

Deney grubuna işbirlikli öğrenme yaklaşımının birleştirme tekniği, kontrol grubuna ise sunuş yoluyla öğretim yaklaşımının anlatım/soru-cevap teknikleri ile dersler işlenmiştir. Öncelikle deney ve kontrol gruplarının birbirine denkliği belirlenmiştir. Bu amaçla iki gruba ön testler yapılarak uygulamaya başlanmıştır. Uygulama altı ders saati sürmüş, uygulamadan bir hafta sonra ise her iki gruba son testler uygulanarak veri toplama aşaması sonlandırılmıştır.

\section{Etik Bildirim}

Bu çalışma Kastamonu Üniversitesi Sosyal ve Beşeri Bilimler Araştırma ve Yayın Etiği Kurulu'nun 12.10.2021 tarih ve 18 sayılı onayı doğrultusunda gerçekleştirilmiştir.

\section{Veri Analizi}

Deney ve kontrol grubunda yer alan öğrencilerin "Türk Grafik Sanatı Tarihi” konusuna yönelik ön test puanlarının normal dağılım özelliği gösterip göstermediğine Shapiro-Wilk testi ile bakılmış, elde edilen sonuçlar Tablo 1 ve Tablo 2 ' de verilmiştir.

Tablo 1. Deney Grubu Ön Test Puanları Normallik Testi

\begin{tabular}{lccc}
\hline Öğretim Modeli & N & Shapiro-Wilk & p \\
\hline İssbirlikli Öğretim Modeli & 20 & .953 & .409 \\
\hline$p>0.05$ & & &
\end{tabular}


Tablo 1'e göre, deney grubu öğrencilerinin ön test puanlarına $(z=.953, p>0.05)$ ilişkin verilerde normal dağılım gözlenmiştir.

Tablo 2. Kontrol Grubu Ön Test Puanları Normallik Testi

\begin{tabular}{lccc}
\hline Ö̆ğretim Modeli & N & Shapiro-Wilk & p \\
\hline İşbirlikli Öğretim Modeli & 19 & .971 & .767 \\
\hline$p>0.05$ & & &
\end{tabular}

Tablo 2'ye göre, kontrol grubu öğrencilerinin ön test puanlarına ( $\mathrm{z}=.971, \mathrm{p}>0.05)$ ilişkin verilerde normal dağılım gözlenmiştir.

Deney ve kontrol gruplarını oluşturan tüm öğrencilerin ön test puan varyanslarının homojen olup olmadığını belirlemek için Levene Testi yapılmış, elde edilen sonuçlar Tablo 3'te verilmiştir.

Tablo 3. Kontrol ve Deney Gruplarının Ön Test Puan Varyanslarının Homojenliği Testi

\begin{tabular}{lccc}
\hline Test & Levene İstatistik (F) & p \\
\hline Ön Test & .002 & .964 \\
\hline$p>0.05$ & &
\end{tabular}

Tablo 3'e göre; deney ve kontrol grublarının ön test puanlarının varyansları arasında istatistiksel olarak anlamlı bir fark bulunmamıştır ( $p>0.05$ ). Deney ve kontrol grubunu oluşturan öğrencilerin ön test $(\mathrm{F}=.002, \mathrm{p}>0.05)$ puanlarına ilişkin verilerde varyansların homojen olduğu söylenebilir. Yapılan normallik ve varyansların homojenliği analizleri sonuçları doğrultusunda çalışmada kullanılacak olan test türü, parametrik test olarak belirlenmiştir.

Kontrol ve deney gruplarını oluşturan öğrencilerin hazır bulunuşluk seviyelerinin eşit olup olmadığının belirlenmesi amacı ile ön test puanları bağımsız gruplar $t$ test ile karşılaştırılmış ve bulgular Tablo 4 'te verilmiştir.

Tablo 4. Kontrol ve Deney Gruplarının Ön Test Puanlarının Karşılaştırılması

\begin{tabular}{|c|c|c|c|c|c|c|}
\hline Öğretim Modeli & $\mathbf{N}$ & $\mathbf{M}$ & $S$ & $\mathrm{df}$ & $\mathbf{t}$ & p \\
\hline İşbirlikli Öğretim Modeli & 20 & 27.55 & 11.52 & \multirow{2}{*}{38} & \multirow{2}{*}{1.52} & \multirow{2}{*}{.137} \\
\hline Sunuş Yoluyla Öğretim Modeli & 19 & 33.00 & 11.15 & & & \\
\hline
\end{tabular}
$p>0.05$

Tablo 4 incelendiğinde; kontrol ve deney gruplarının ön test puanları $(\mathrm{t}(38)=1.52, \mathrm{p}=.137)$ arasında istatistiksel olarak anlamlı bir fark yoktur. Bu sonuçlara göre; kontrol ve deney gruplarını oluşturan öğrencilerin hazır bulunuşluk düzeylerinin birbirine benzer olduğu söylenebilir.

Kontrol ve deney gruplarının ön test-son test puanlarının karşılaştırılması için bağımlı örneklemler $\mathrm{t}$ testi kullanılmıştır. Kontrol ve deney gruplarının son test puanlarının karşılaştırılması amacıyla ise bağımsız örneklemler $\mathrm{t}$ testi kullanılmıştır.

\section{Bulgular}

Tablo 5. Kontrol ve Deney Gruplarının Ön Test-Son Test Puanlarının Karşılaştırılması

\begin{tabular}{llllll}
\hline Öğretim Modeli & $\mathbf{N}$ & $\begin{array}{l}\text { Ön Test } \\
(\overline{\boldsymbol{x}} \pm \mathbf{S})\end{array}$ & $\begin{array}{l}\text { Son Test } \\
(\overline{\boldsymbol{x}} \pm \mathbf{S})\end{array}$ & $\mathbf{t}$ & $\mathbf{p}$ \\
\hline İşbirlikli Öğretim Modeli & 20 & $27.55 \pm 11.52$ & $70.45 \pm 12.18$ & 14.66 & $.000^{*}$ \\
\hline Sunuş Yoluyla Öğretim Modeli & 19 & $33.00 \pm 11.15$ & $83.45 \pm 12.70$ & 13.69 & $.000^{*}$ \\
\hline${ }^{*} p<0.05$ & & & & &
\end{tabular}

Tablo 5'te görüldüğü gibi; deney grubunda işbirlikli öğretim modeli ile eğitim yapılmadan önce (ön testte) öğrencilerin testten aldıkları puanların ortalaması 27.55 ve standart sapması ise 11.52 'dir. 
İşbirlikli öğretim modeli ile dersler işlendikten sonraki (son teste) testten aldıkları puanların ortalaması 70.45 ve standart sapması ise $12.18^{\prime}$ dir. Yapılan bağımlı örneklemler t-testinin sonuçlarına göre öğrencilere uygulanan işbirlikli öğretim modeli öğrencilerin testten aldıkları puanların ortalamasını $70.45^{\prime}$ e yükselecek biçimde ve standart sapmasını ise 12.18 olacak şekilde etki etmiştir, $\mathrm{t}(20)=14.66$; $\mathrm{p}<0.05$ ve $\mathrm{r}^{2}=0.92$. Öğrencilerin Türk Grafik Sanatı Tarihi konusuna yönelik yapılan testten aldıkları puanların ortalamasındaki varyansın \%92'si derslerin İşbirlikli Öğretim Modeli ile işlenmesinden kaynaklanmaktadır. Bu değer Cohen'e (1988) göre büyük etki olarak kabul edilmektedir.

Kontrol grubunda sunuş yoluyla öğretim modeli ile eğitim yapılmadan önce (ön testte) öğrencilerin testten aldıkları puanların ortalaması 33.00 ve standart sapması ise 11.15 tir. Yapılan bağımlı örneklemler t-testinin sonuçlarına göre öğrencilere uygulanan sunuş yoluyla öğretim modeli öğrencilerin testten aldıkları puanların ortalamasını 83.45'e yükselecek biçimde ve standart sapması ise 12.70 olacak şekilde etki etmiştir, $t(19)=13.69 ; \mathrm{p}<0.05$ ve $\mathrm{r}^{2}=0.92$. Öğrencilerin Türk Grafik Sanatı Tarihi konusuna yönelik yapılan testten aldıkları puanların ortalamasındaki varyansın \%91'i derslerin sunuş yoluyla öğretim modeli ile işlenmesinden kaynaklanmaktadır. Bu değer Cohen'e (1988) göre büyük etki olarak kabul edilmektedir.

Tablo 6. Kontrol ve Deney Gruplarının Son Test Puanlarının Karşılaştırılması

\begin{tabular}{llccc}
\hline Öğretim Modeli & $\mathbf{N}$ & $\mathbf{(} \overline{\boldsymbol{x}} \pm \mathbf{S})$ & $\mathbf{t}$ & $\mathbf{p}$ \\
\hline İşbirlikli Öğretim Modeli & 20 & $70.45 \pm 12.18$ & \multirow{2}{*}{3.30} & \multirow{2}{*}{$.002^{*}$} \\
\cline { 1 - 3 } Sunuş Yoluyla Öğretim Modeli & 19 & $83.45 \pm 12.70$ & & \\
\cline { 1 - 2 }${ }^{*} p<0.05$ & & &
\end{tabular}

Deney grubu öğrencilerinin son test puanlarının ortalaması $(\overline{\boldsymbol{x}}=70.45, \mathrm{~S}=12.18)$, kontrol grubunda yer alan öğrencilerin son test puanlarının ortalamasından $(\bar{x}=83.45, \mathrm{~S}=12.70)$ düşüktür. Ortalamalar arasındaki fark anlamlıdır. $\mathrm{t}(38)=3.30, \mathrm{p}<.05, \mathrm{r}^{2}=0.23$. Cohen'e (1988) göre bu hesaplanan etki büyüklüğü $\left(\mathrm{r}^{2}\right)$ değeri orta etki olarak kabul edilmektedir. Son test puanlarındaki varyansın \%23'ünü öğretim yöntemi açıklamaktadır. Bu bulguya göre; her iki grubun başarı düzeyi artmış olsa da sunuş yoluyla öğretim modeli kullanılarak işlenen Türk Grafik Sanatı Tarihi konusuna yönelik kontrol grubu öğrencilerinin başarı düzeyleri, işbirlikli öğretim modeli grubunda yer alan deney öğrencilerine göre yüksek düzeyde olduğu tespit edilmiştir.

\section{Sonuç ve Öneriler}

$\mathrm{Bu}$ araştırmanın bulgularına göre;

Araştırmanın bulgularına dayalı olarak işbirlikli öğrenme ortamında öğrenim gören deney grubu öğrencileri ile sunuş yolula öğretimin uygulandığı kontrol grubu öğrencilerinin çalışma öncesinde başarı düzeylerinin denk olduğu tespit edilmiştir.

Hem işbirlikli öğretim modeli hem de sunuş yoluyla öğretim modeli ile işlenen Türk Grafik Sanatı Tarihi konusu; öğrencilerin başarılarını geliştirmelerini sağlamıştır. Her iki yöntemde de öğrencilerin ön test ve son test puanları arasında anlamlı fark olduğu ortaya çıkmıştır.

İşbirlikli öğretim modeli ve sunuş yoluyla öğretim modeli ile Türk Grafik Sanatı Tarihi konusunu işleyen öğrencilerin bu dersteki başarı puanları arasında son test lehine anlamlı bir fark olduğu sonucuna ulaşılmıştır. Sunuş yoluyla öğretim modeli öğrencilerin ders başarılarına işbirlikli öğretim modelinden daha yüksek katkı sağlamıştır. Baran (2013) “Probleme Dayalı Öğrenme ile Sunuş Yoluyla Öğretim Yaklaşımlarının Öğrencilerin Bilişsel Öğrenme Düzeyleri Açısından Karşılaştırılması" başlıklı çalışmasında ön test son test karşılaştırma gruplu deneysel model kullanmış ve sunuş yoluyla 
öğretim modeli ile öğrencilerin akademik başarılarında istatistiksel olarak anlamlı bir artış görüldüğünü ortaya koymuştur. Araştırmanın bu sonucu bu çalışmayı destekler niteliktedir.

Hangi öğretim yöntemi uygulanırsa uygulansın başarının artışı şaşırtıcı değildir, bu durum öğretimin doğal bir sonucu olarak kabul edilir. Bu sebeple bu araştırmanın yanı sıra işbirlikli öğrenme yaklaşımının öğrenci başarısı üzerinde olumlu etki sağladığına yönelik çalışmalar da (Aydal, 2017; Aydın ve Alakuş, 2009; Tarlakazan, 2010; Yılmaz, 2007) mevcuttur.

Türk Grafik Sanatı Tarihi konusunun bu çalışmada kullanılan yaklaşımlardan farklı öğretim yaklaşımları ile işlendiği çalışmalar yapılarak bu konunun öğretiminde hangi öğretim yaklaşımının daha etkili olduğu belirlenmeye çalışılabilir.

Farklı gruplarla buna benzer çalışmaların yapılması, bu çalışmanın sonuçlarının genellenebilmesi ya da daha güvenilir sonuçlara ulaşılması açısından önemlidir.

Bunlara ek olarak çalışmanın sonuçlarından ziyade araştırmacının gözlemleri dikkate alındığında işbirlikli öğrenme yaklaşımının uygulanması sırasında öğrencilerin sosyalleştikleri, özgüven kazandıkları, konu anlattıkları için kendilerini değerli hissettikleri gözlenmiştir. Bu kazanımların amaç edinildiği gruplarda derslerin işbirlikli öğrenme yaklaşımı ile işlenmesi önerilebilir.

\section{Kaynaklar}

Akbay, T. (2021). Deneysel araştırmalar. S. Şen ve İ. Yıldırım (Ed.), Ĕ̆itimde araştırma yöntemleri. Ankara: Nobel.

Akınoğlu, O. (2018). Öğretim stratejileri. A. Arı (Ed.), Öğretim ilke ve yöntemleri içinde (s. 67-84). Konya: Eğitim.

Aydal, M. (2017). İşbirlikli öğrenmeye dayah öğrenme yaklaşımının görsel sanatlar dersindeki erişiye, tutuma ve öğrenilenlerin kalıcllğına etkisi. Doktora Tezi. Necmettin Erbakan Üniversitesi Eğitim Bilimleri Enstitüsü, Konya.

Aydın, S. ve Alakuş, A. O. (2009). İşbirlikli öğrenmeyle görsel sanatlar dersini işlemenin öğrencilerin başarısına ve öğrenilenlerin kalıcılığına etkisi. Dicle Üniversitesi Ziya Gökalp Eğitim Fakültesi Dergisi, 13, 63-67.

Baran, T. (2013). Probleme dayalı öğrenme ile sunuş yoluyla öğretim yaklaşımlarının öğrencilerin bilişsel öğrenme düzeyleri açısından karşılaştırılması. Yüksek Lisans Tezi. Kocaeli Üniversitesi Fen Bilimleri Enstitüsü, Kocaeli.

Bilen, M. (1996). Plandan uygulamaya öğretim. Ankara: Aydan.

Cohen, J. (1998). The analysis of variance in statistical power analysis for the behavioral sciences. Lawrence Erlbaum Associates, 274-287.

Ergün, M. ve Özdaş, A. (1997). Öğretim ilke ve metodları. http://mustafaergun.com.tr/wordpress/wpcontent/uploads/2016/01/oiy.pdf sayfasından erişilmiştir.

Karaağaçlı, M. (2011). Öğretimde kuramlar ve yaklaşımlar. Ankara: Sage.

Karasar, N. (2016). Bilimsel araştırma yöntemi: Kavramlar ilkeler ve teknikler (31. Basım). Ankara: Nobel.

Özdilek, K., Erkol, M., Doğan, A., Doymuş, K. ve Karaçöp, A. (2015). Fen ve teknoloji dersinin öğretiminde Jigsaw tekniğinin etkisi ve bu teknik hakkında öğrenci görüşleri. Erzincan Eğitim Fakültesi Dergisi, 12(2), 209-225. 
Özer, M. A. (2005). Etkin öğrenmede yeni arayışlar. Bilig Türk Dünyası Sosyal Bilimler Dergisi, Güz(35), 105-131.

Özpolat, V. (2013). Öğretmenlerin mesleki önceliklerinde öğrenci merkezli eğitim yaklaşımının yeri. Milli Ĕ̆itim Dergisi, 200, 5- 27.

Özsoy, V. (2003). Görsel sanatlar eğitimi resim-i̧̧ eğitiminin tarihsel ve düşünsel temelleri. Ankara: Gündüz.

Senemoğlu, N. (2011). Gelişim, öğrenme ve öğretim (20. Basım). Ankara: Pegem.

Sönmez, V. (2009). Program geliştirmede öğretmen el kitabı (15. Basım). Ankara: Anı.

Tarlakazan, E. (2010). Illköğretim görsel sanatlar dersi 6. sını kazanımlarının işbirlikli öğrenme yöntemi etkinlikleri ile gerçekleştirilmesinin öğrenci erişisine etkisi. Doktora Tezi. Gazi Ünivereitesi, Eğitim Bilimleri Enstitüsü, Ankara.

Yılmaz, M. (2007). Görsel sanatlar eğitiminde işbirlikli öğrenme. Kastamonu Eğitim Dergisi, 15(2), 747756.

\section{Yazarların Katkı Oranı Beyanı}

Araştırmanın çalışma süreçleri birinci yazar tarafından planlanmış ve uygulanmıştır. Kontroller ise ikinci yazar tarafından yapılmıştır.

\section{Destek ve Teşekkür Beyanı}

Bu araştırmada herhangi bir kurum, kuruluş ya da kişiden destek alınmamıştır.

\section{Çatışma Beyanı}

Araştırma ile ilgili diğer kişi ve kurumlarla herhangi bir kişisel ve finansal çıar çatışması yoktur.

\section{Etik Bildirim}

Bu çalışma Kastamonu Üniversitesi Sosyal ve Beşeri Bilimler Araştırma ve Yayın Etiği Kurulu'nun 12.10.2021 tarih ve 18 sayılı onayı doğrultusunda gerçekleştirilmiştir. 